\title{
FRANCK COLLARD, Les écrits sur les poisons
}

\section{Maria Colombo Timelli}

\section{OpenEdition \\ Journals}

Édition électronique

URL : https://journals.openedition.org/studifrancesi/12455

DOI : 10.4000/studifrancesi. 12455

ISSN : 2421-5856

\section{Éditeur}

Rosenberg \& Sellier

\section{Édition imprimée}

Date de publication : 1 avril 2018

Pagination : 106-107

ISSN : 0039-2944

\section{Référence électronique}

Maria Colombo Timelli, « Franck collard, Les écrits sur les poisons », Studi Francesi [En ligne], 184 (LXII I

I) | 2018, mis en ligne le 04 juillet 2018, consulté le 15 novembre 2021. URL : http://

journals.openedition.org/studifrancesi/12455; DOI : https://doi.org/10.4000/studifrancesi.12455

Ce document a été généré automatiquement le 15 novembre 2021.

\section{(c)}

Studi Francesi è distribuita con Licenza Creative Commons Attribuzione - Non commerciale - Non opere derivate 4.0 Internazionale. 


\title{
FRANCK COLLARD, Les écrits sur les poisons
}

\author{
Maria Colombo Timelli
}

\section{RÉFÉRENCE}

FRANCK COLLARD, Les écrits sur les poisons, Turnhout, Brepols, 2016, « Typologie des sources du Moyen Âge occidental» 88, 196 pp.

1 La parution d'un fascicule de la collection «Typologie des sources du Moyen Âge occidental» mérite assurément d'être signalée, dans la mesure où chacun de ces volumes offre à la fois un panoramique bibliographique et critique vaste sur un sujet donné en constituant ainsi la base incontournable pour les recherches ultérieures. Conformément aux règles de la série, le volume de Franck Collard s'ouvre sur une Bibliographie raisonnée qui encadre le sujet, pour discuter ensuite les questions rattachées au « genre» en question.

2 Un corpus de textes vénénologiques, assez disparates quant à leur contenu, s'est constitué à partir des années ' 90 du XIII' siècle : entre cette date et 1500 - terminus ante quem de la «Typologie» - il compte une trentaine d'œuvres à la fortune variée, produites surtout en Italie en milieu universitaire, toutes rédigées en latin. L'inventaire donné en annexe énumère les titres retenus; signalons que, face à de nombreuses traductions en italien et à de rares versions castillanes, on ne dénombre qu'une seule traduction en français : il s'agit du Tractatus de venenis de Pietro d'Abano, composé entre 1303 et 1316 (l'œuvre de loin la plus diffusée dans l'Europe entière, avec plus de 70 manuscrits, 35 éditions anciennes dont une vingtaine d'incunables), traduit par le carme Philippe Ogier pour le maréchal de Boucicaut en 1402 (Paris, BnF, fr. 14820), puis de nouveau par Lazare Boët et imprimé à Lyon en 1593. 